\title{
PRODUCTION OF LOW CALORIES AND SODIUM CAST FETA CHEESE
}

Azhary $^{1^{*}}$ A.M., Meranda A. Tawfek ${ }^{1}$, Emam ${ }^{2}$ A.O. and Fayed ${ }^{2}$ A.E.

1- Dairy Sci., \& Technol. Res. Dept., Food Tech. Res. Institute, Agric. Res. Center, Giza, Egypt

2- Food Sci. Dept., Fac. of Agric., Ain Shams Univ., P.O. Box 68, Hadayek Shobra 11241, Cairo, Egypt

${ }^{*}$ Corresponding author: ahmedmohe530@gmail.com

\section{ABSTRACT}

The aim is to investigate the production of cast Feta cheese low in energy by partial or full replacement of milk fat and $\mathrm{NaCl}$ using, in order maltodextrin as a fat replacer and $\mathrm{KCL}$ as a salting substitute.

Cast Feta cheese was made using skimmed milk powder which was arithmetically mixed with dried milk protein concentrate and reconstituted to form total solids of $21 \%$ and $12 \%$ protein. In the base of full cream cheese, the fat was adjusted to $16 \%$ using butter oil (the control). For other treatments, butter oil was replaced with maltodextrin at the level of nil, 25, 50, 75 or $100 \%$. All formulas were heat treated and homogenized then cooled to the suitable renneting temperature. Salted to $2.5 \%$ $\mathrm{NaCl}$, whether alone or replaced with $\mathrm{KCl}$ at the level of nil, 25,50 or $75 \%$. Glucono delta lactone was added at the level of $2.5 \%$ then rennet solution was added at the rate of $2 \mathrm{ml} / 10 \mathrm{Kg}$ precheese, which was packaged into plastic containers and incubated at $40^{\circ} \mathrm{C}$ for the complete coagulation. All cheese containers were cold stored at $5^{\circ}$ C for 3 months.

The proportional fat replacement with maltodextrin led to gradual reduction in the dry matter (DM) and ash contents of resultant cheese. The repining indices; titratable acidity, water soluble nitrogen (WSN) on total nitrogen (TN) and nonprotein nitrogen / TN contents were increased as the fat replacement increased. Hardness, chewiness and gumminess of cheese increased while cohesiveness decreased. Total bacterial count (TBC) increased while, yeasts and molds (Y\&M) count decreased. All judging scores of cheese sensory attributes. The substitution of $\mathrm{NaCl}$ with $\mathrm{KCl}$ in cheese salting heightened the $\mathrm{DM}$ and protein contents. Cheese hardness was weakened while gumminess was strengthened while, decreased in TBC and Y\&M count. Nevertheless, scores of sensory properties were declined by $\mathrm{NaCl}$ substitution by more than $50 \%$. During cheese cold storage period (CSP) TA, WSNITN and NPNITN contents as well as Y\&M count were increased while $\mathrm{pH}$ value lowered. All texture parameters and organoleptic attributes, scores of cheeses decreased by prolonging the CSP but still keeping their acceptable quality until the end of experimental CSP.

Keywords: Chemical composition, Repining indices, Microbiological quality, Texture profile

\section{INTRODUCTUION}

Feta is a white soft cheese of high quality, manufactured from sheep's milk or from a mixture of sheep's and goat's milks, of which the latter must not exceed $30 \%$ of the total cheese milk according to a specific technology, which is dried salted, manufactured and stored in brine. The final concentration of salt in the cheese mass should be $\sim 3 \mathrm{~g} 100 \mathrm{~g}^{-1}$. It has a salty, slightly acid taste, and pleasant sensory properties that nowadays have a worldwide acceptance. The maximum moisture

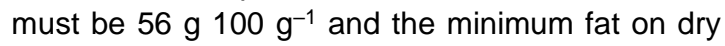

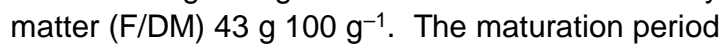
must be at least 60 days. For many centuries, Feta cheese was known only in the Balkan region. However, during the $20^{\text {th }}$ century, large Greek communities were established in various countries, mainly in Australia, USA, Canada and Germany, due to mass migration of Greeks, who retained their dietary habits. Moreover, during the last 30 years, new markets for Feta have evolved in the Middle East. Since the available quantities of traditional Feta cheese were not sufficient to meet the demand in different parts of the world, attempts 
have been made to substitute sheep's milk with cow's milk for the manufacture of Feta-type cheese. In order to 'mimic' the sensory properties of traditional Feta cheese, chlorophyll, glucono delta lactone (GDL) as well as lipase, were added to the cow's milk before renneting, and the manufacturing procedure was modified. However, despite their good quality, cow's milk brined cheeses never acquired the qualities of traditional Feta. Some European countries have exported to Middle East markets large quantities of brined cheeses made with the addition of milk powder, caseinates, caseins, whey proteins, or made from ultrafiltrated (UF) cow's milk under the name Feta (Tamime, 2006).

Since about four decades, the requirement to special foods and rather low calorie dairy products industry, e.g., via fat replacement, becomes an inevitable consumption demand to face some healthy problems.

The increased affluence in western society has resulted in excessive calorie intake, and expert panels have recommended reduction in the intake of both total and saturated fat (O'Brien and O'Connor, 2004). Dietary fat has been shown to be associated with an increased risk of obesity, atherosclerosis, coronary heart disease, elevated blood pressure, and tissue injury diseases associated with the oxidation of unsaturated fats (Doyle and Pariza, 2002). This has created increased consumer concern over the implications of dietary fat on health, and large increases in the supply, and demand for, low-fat foods, including cheese (Dexheimer, 1992). However, it is generally acknowledged by market experts that the consumption of low- and reduced-fat cheeses remained relatively low (e.g., $8 \%$ of total cheese in the UK) throughout the 1990s, though some current commercial information indicates large increases in the market for low-fat cheese varieties (Guinee and McSweeney, 2006).

On the other hand, sodium intake is known to be essential for human health as it is one of the main electrolyte components of extracellular fluids. It enables the transport of nutrients and contributes to the regulation of blood pressure, transfer of intracellular water, regulation of osmotic pressure, and transmission of nerve impulses (Cruz et al 2011). The recommended sodium daily intake is $2.4 \mathrm{~g}$ for healthy adults, which is equivalent to $6 \mathrm{~g}$ $\mathrm{NaCl}$ (Kaplan, 2000).
However, an excessive dietary sodium intake, mostly in industrialized developed countries being usually about 5 to 6 times higher than the maximum recommended daily intake (Drake et al 2011), which is associated with unhealthy effects, such as blood pressure increase with the very likely development of cardiovascular diseases, such as heart attack and strokes (Salahdeen and Alada, 2007) stomach cancer and diabetes or increment of calcium renal excretion, due to lower calcium absorption, which may lead to osteoporosis and to incidence of renal calculi (kidney stones) (Adeniyi and Fasanmade, 2006). The efficacy of reducing sodium intake in lowering blood pressure is well established. Due to the aforementioned effects, reduction of sodium chloride contents in food is one of the main focuses of attention in the European Union, as it is known that the mean daily salt intake in the European population ranges from 8 to $11 \mathrm{~g}$ salt/day ( $3-5 \mathrm{~g}$ of sodium). The Regulation (EC) No. 1924/2006 on nutrition and health claims made on foods allows "low sodium/salt," "very low sodium/ salt," and "sodium-free or saltfree" labelling for foods containing low salt levels, in agreement with the fixed limit.

A successful development of low calorie and lor low sodium product depends on whether it is possible to copy the organoleptical qualities the equivalent standard product have. Consequently, it is often necessary to develop an entirely new recipe in order to obtain a similar acceptance of the low calorie version of the product (El-Sayed et al 2003).

For that in view, the present study was aimed to experiment the combination between milk fat and $\mathrm{NaCl}$ substitution for reducing calories and sodium ion to find out to what extent they would maintain their physical properties and sensory acceptance.

\section{MATERIALS AND METHODS}

\section{Materials}

Skimmed milk powder $(1.25 \pm 0.01 \%$ fat, $4 \pm 0.03 \%$ moisture, $52 \pm 0.11 \%$ lactose, $36 \pm 0.08 \%$ protein and $8 \pm 0.05 \%$ ash) was obtained from Valio Ltd, Helsinki- Finland. Milk protein concentrate (69.8 $\pm 0.08 \%$ protein, $17 \pm 0.11 \%$ lactose, $1.4 \pm 0.01 \%$ fat, $7.2 \pm 0.05 \%$ ash and $4.6 \%$ moisture) was obtained from Fonterra Ltd 9Princes Street Auckland- NewZeland. Maltodextrin ( $\leq 0.6 \%$ ash and $\leq 0.5 \%$ moisture) was obtained from Tiba 
Starch, Glucose Manufacturing Co., Al-Salheya AlGadeda, Sharkia, Egypt. Microbial rennet powder (Reniplus 2000 IMCU) produced of Caglio Star, Proquiga, Spain was purchased from Mohamed Seif El-Din Co., for dairy tools, Ramses, Egypt. Glucono delta lactone (GDL) was obtained from Shandong Kaison Biochemical Co., Ltd, Wulian Country, Shandong, China. Dry fine grade sodium chloride $(\mathrm{NaCl})$ was obtained from El-Nasr for Salt Production Co., Alexandria, Egypt. Food grade potassium chloride $(\mathrm{KCl})$ was obtained from Alpha Chemik, India, while potassium sorbate was obtained from SJZ Chem-Pharm Co., Ltd. China.

\section{Experimental procedure}

\section{Preparation of Feta cheese}

Feta cheeses were produced according to the flow diagram shown in Fig. (1) whereas skim milk powder (SMP) was arithmetically mixed with dried milk protein concentrate (DMPC) and reconstituted with warm tap water at $45^{\circ} \mathrm{C}$ providing that the final formulation should be contained the total solids (TS) of $21 \%$ and $12 \%$ protein. In the base of full cream Feta cheese, the fat content was adjusted to $16 \%$ using butter oil (the control). For other treatments, butter oil was replaced with maltodextrin at the level of nil, $25,50,75$ or $100 \%$. All formulas were heat treated at $72^{\circ} \mathrm{C}$ for $2 \mathrm{~min}$., at which they were homogenized at 200 bar using APV Rannie Apparatus. Then they were cooled to the suitable renneting temperature (at $40^{\circ} \mathrm{C}$ ).

Potassium sorbate was added at the level of $0.015 \%$ and salted to $2.5 \% \mathrm{NaCl}$, whether alone or replaced by $\mathrm{KCl}$ at the level of nil, 25,50 or $75 \%$. GDL was added at the level of $2.5 \%$ GDL then fresh prepared rennet solution was added at the rate of $2 \mathrm{ml} / 10 \mathrm{Kg}$ pre-cheese, which was packaged into plastic containers and incubated at the same temperature for the complete coagulation (within $30 \mathrm{~min}$.) . All cheese containers were cold stored at $5^{\circ} \mathrm{C}$ for 3 months. Three replicates were carried out for each treatment.

\section{Analytical methods}

Dry matter, fat, total nitrogen, ash and titratable acidity (TA) contents were determined according to AOAC (2012). The $\mathrm{pH}$ values for the produced cheese samples were measured using electric $\mathrm{pH}$ meter "HANNA" with combined glass electrode (Electric Instruments Limited) at $20^{\circ} \mathrm{C}$ after calibrating with fresh $\mathrm{pH} 4.0$ and 7.0 standard buffers according to the methods of BSI (1990). The Water soluble nitrogen (WSN) was determined ac- cording to the method described by Ling (1963). The textural profile analysis test (TPA) for some textural properties (hardness, springiness, cohesiveness, gumminess and chewiness) were measured by LFRA-Texture analyzer (1000) using computer interface software (CNS Farnell, Bore Harwood, Hertfordshire, England WD6 1WG) according to Bourne (2002). Two-bite compression of cylindrical samples of $2.4 \mathrm{~cm}$ of diameter and 3.0 $\mathrm{cm}$ of height by an aluminum plate $(10 \times 9 \mathrm{~cm})$ was performed. The compression ratio employed was of $20 \%$ deformation from the initial height of the sample at a rate of $2 \mathrm{~mm} \mathrm{sec}^{-1}$. The cheese samples were left at room temperature $\left(25^{\circ} \mathrm{C}\right)$ for 20 min. prior to testing. Total bacterial count (TBC) was enumerated using tryptone glucose yeast agar medium at $32^{\circ} \mathrm{C}$ for $48 \mathrm{~h}$ according to APHA (1992). Yeasts \& Molds were enumerated using oxytetracycline glucose yeast extract agar (OGYR agar) at $25-27^{\circ} \mathrm{C}$ for 4 days according to (APHA, 1992). Sensorial properties were evaluated by regular score panels including the staff members of Food Science Department, Faculty of Agriculture, Ain Shams University. Sensory characteristics were appearance (5 points), body and texture (5 points), flavor (5 points) with total score of 15 points, according to Pearce and Heap (1974). The data obtained were exposed to proper statistical analysis according to statistical analyses system user's guide (SAS, 1996).

\section{RESULTS AND DISCUSSION}

\section{Chemical composition of cast Feta cheese}

Data given in Table (1) reveal that, the replacement of fat and/or salt led to significant decrease in the DM content of ed resultant cheese. Moreover replacing the $\mathrm{NaCl}$ with $\mathrm{KCl}$ by 25 or $50 \%$ led to obtain the highest DM of all cheese samples, while the total replacement of fat with maltodextrin led to significantly lowest level of DM. The DM content of all experimental cheese samples are in accordance to the legal standard of EOSQ (2005).

Regarding the protein content, data stated that, there were significant differences due to the fat and salt replacement. Replacing the fat at the rate of $25 \%$ led to attain the highest protein level in all samples, while the full fat control cheese was associated with the lowest protein content. The protein content of cheeses didn't differ significantly after exceeding the $50 \%$ fat replacement rate. While, replacing $25 \%$ of the salt with $\mathrm{KCl}$ led to obtain the highest significant protein level of all cheese samples. 


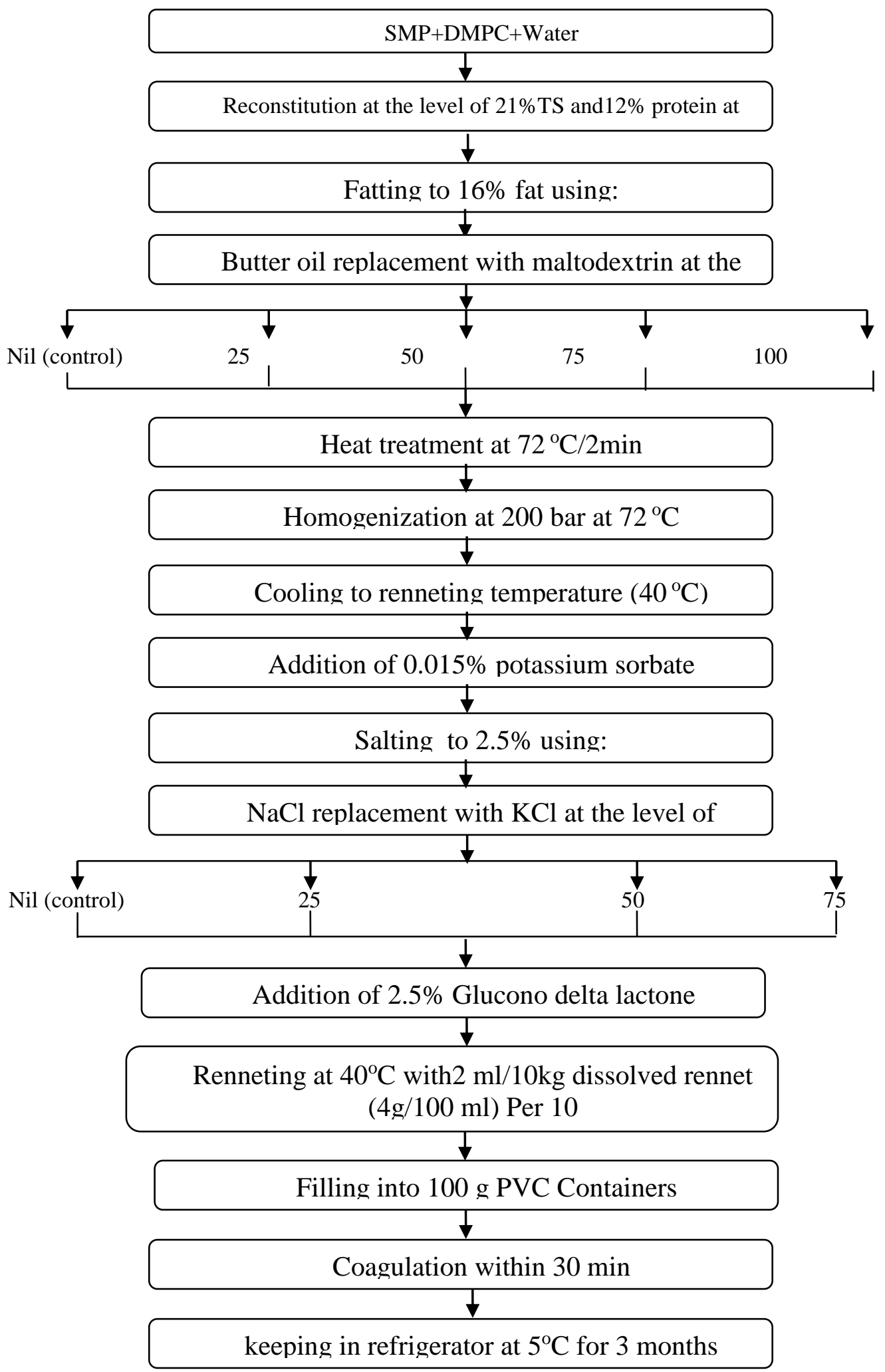

Fig. 1. Flow diagram of cast Feta cheese from skimmed milk powder (SMP) and dried milk protein concentrate (DMPC) with fat and/or $\mathrm{NaCl}$ replacement 


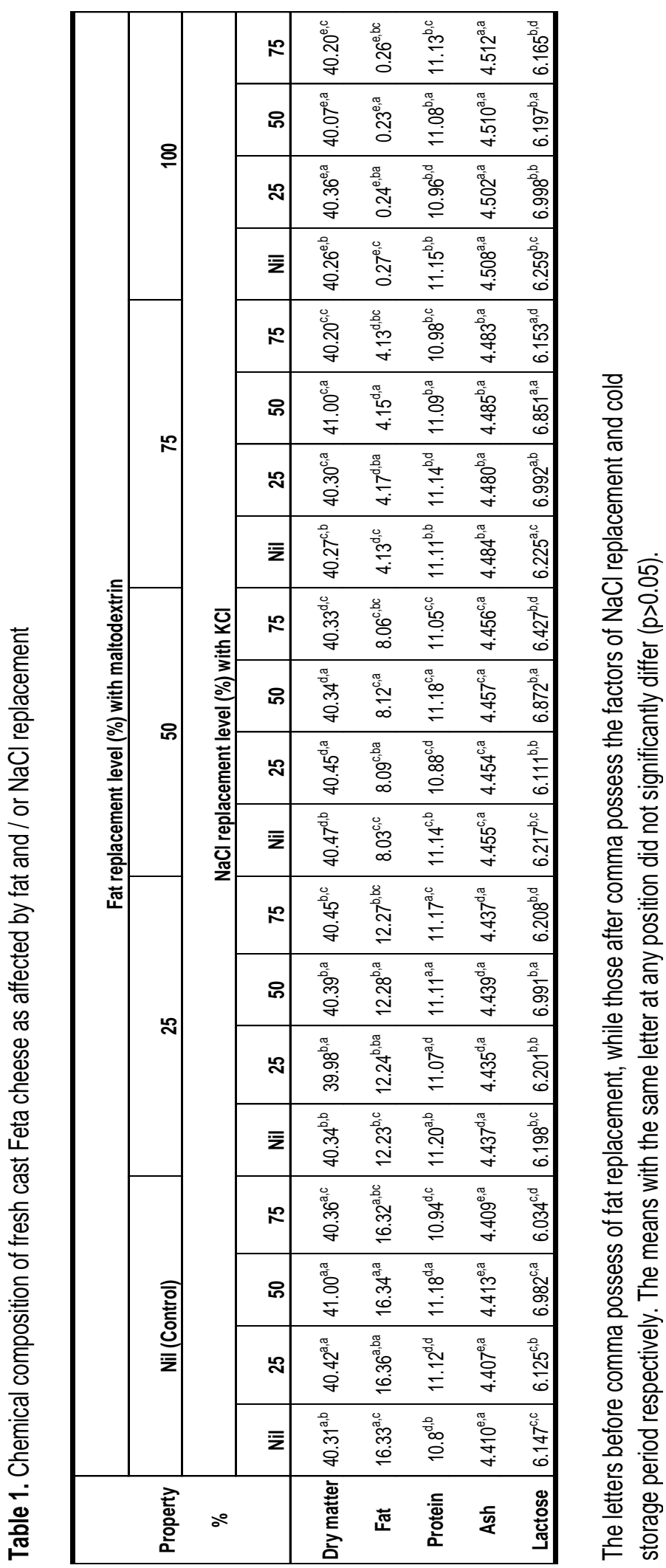


Concerning the fat content, the statistical analysis confirmed that, the differences occurred due to the fat replacement were significant. On the other hand the half replacement of $\mathrm{NaCl}$ with $\mathrm{KCl}$ was associated with the highest fat level compared with the control cheese which gained the lowest fat content of all experimental cheeses.

With regard to the ash content, the statistical analysis confirmed that the ash contents of cheeses were increased significantly with the increase in fat replacement rates. This could be ascribed essentially to higher ash content of the maltodextrin whilst the fat is, indeed ash free. Nevertheless, the salt replacement did not cause any significant differences in ash contents. This possibly due to that the purity and molecular weight of $\mathrm{NaCl}$ and $\mathrm{KCl}$ are near to each other.

Lactose content of low fat, low salt Feta cheese exhibited that, replacing the fat with maltodextrin led to increase the lactose content in cheese, while the control cheese which was made without fat replacement showed the lowest among all cheeses. Amongst the fat replaced cheeses, the $75 \%$ fat replaced cheese was characterized with the highest lactose level of all experimental cheese samples, while the cheeses of 25, 50 and $100 \%$ fat replacement are statistically similar to each other in their lactose. With regard to the $\mathrm{NaCl}$ salt replacement, data stated that, the $50 \%$ salt replaced cheese showed the highest lactose content of all samples, while the $75 \%$ salt replacement cheese was distinguished with the lowest level of lactose.

\section{Ripening indices of cast Feta cheese}

\subsection{Titratable acidity and $\mathrm{pH}$ values of cast Feta cheese}

Data presented in Table (2) revealed that, the cast Feta cheese made with the total fat replacement gained the highest Titratable acidity (TA), while lower fat replacement ratios with maltodextrin led to obtain TA contents similar to the control cheese. This could be due to lack in purity of used maltodextrin. Moreover, the $\mathrm{NaCl}$ salt replacement with $\mathrm{KCl}$ had no obvious effect on $\mathrm{TA} \%$ of the obtained cheeses. By prolonging the cold storage period, the TA\% of all cheese samples was gradually increased until the end of experimental period, likely due to residual carbohydrate fermentation.
Similar observations were reported by El-batawy et al (2004).

Although, $\mathrm{pH}$ values appeared non significant responses toward the replacing of cheese fat with maltodextrin at the rate of $25 \%$ even along the studied cold storage period, the increase in the replacement ratio led to increase the cheese $\mathrm{pH}$ value until the level of $75 \%$. However, the total replacement of fat with maltodextrin led to obtain the lowest significant level of $\mathrm{pH}$ value. Moreover, the $\mathrm{NaCl}$ replacement led to decrease the cheese $\mathrm{pH}$ value regardless the replacement level. During the cold storage, the $\mathrm{pH}$ value of all cheeses decreased gradually up to the end of the experimental storage period, possibly due to the increase in lactic acid due to the growth and activity of the remaining lactic acid bacteria.

\subsection{Water soluble nitrogen and non-protein nitrogen contents of cast Feta cheese}

Data given in Table (3) are the water soluble nitrogen (WSN) and non-protein nitrogen (NPN) contents expressed on total nitrogen (TN) of cast Feta cheese.

The obtained results revealed that addition of maltodextrin as a partial replacer of cheese fat had no effect on the WSN/TN of cheese samples, while the totally fat replaced cheese expressed highest significant level of the WSN/TN. This could be ascribed to the relatively harmful effect of fat on the proteolysis rate by the cheese microflora. Similar observations were reported by Fenelon et al (2000). With respect to $\mathrm{NaCl}$ replacement, only the $50 \% \mathrm{NaCl}$ replacement rate led to increase the WSN of cheese compared either with the control or cheeses treatments with the other $\mathrm{NaCl}$ replacement ratios.

With regard to the cheese NPN/TN, the results reveal ed that, the NPN/TN values were gradually increased by increasing the fat replacement rateed. Unlikely, the addition of $\mathrm{KCl}$ instead of $\mathrm{NaCl}$ had no significant effect on the NPN/TN until the $50 \%$ replacement rate.

Both the WSN/TN and NPN/TN contents were gradually increased by prolonging the cold storage period. Similar findings were previously reported by Tunick et al (1991). 


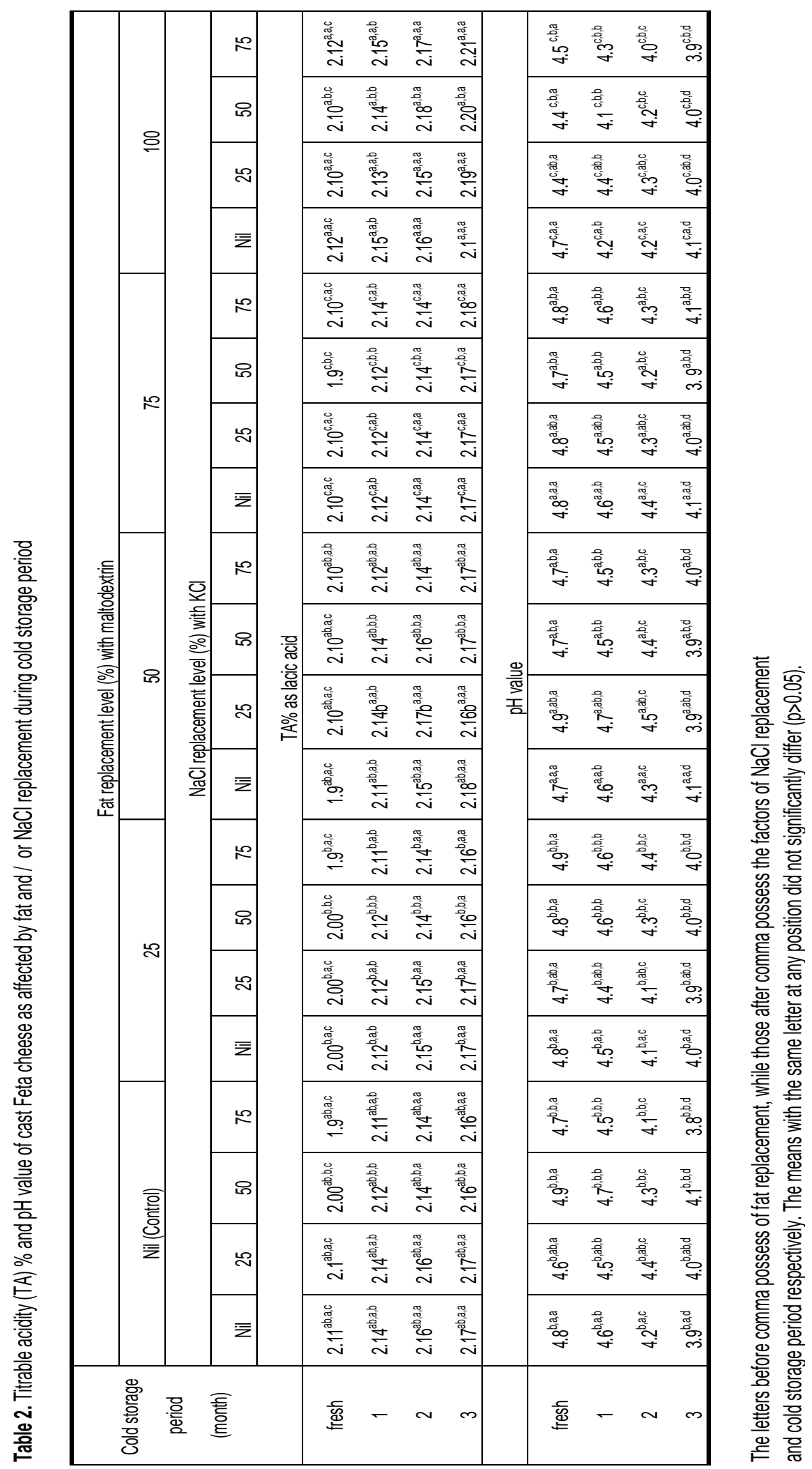




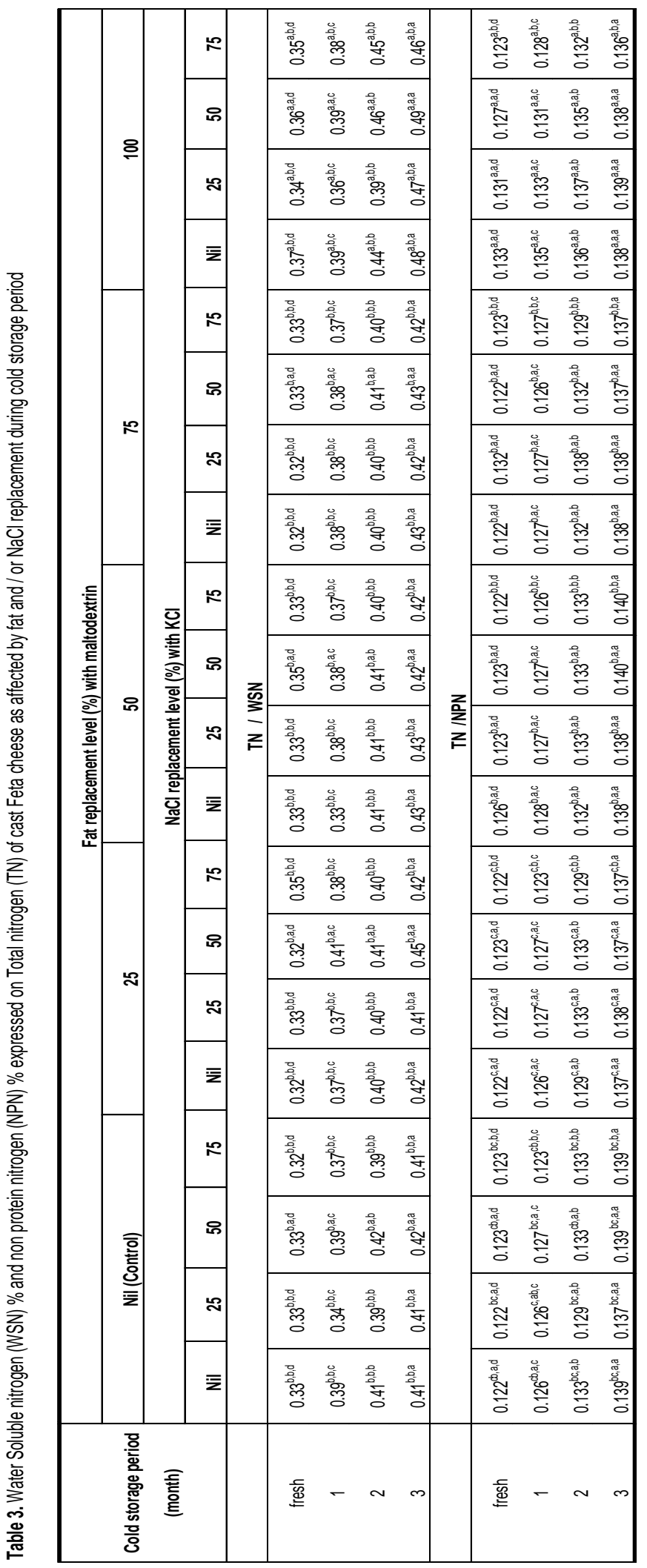




\section{Texture profile of cast Feta cheese}

The parameters expressing texture profile are reflecting the matrix situation of cheese. These parameters are hardness, cohesiveness, springiness, gumminess and chewiness.

Hardness is the force required to compress a sample between the molars as explained by Bourne (2002). Data illustrated in Table (4) indicated that the hardness of the cast Feta cheese differed significantly by the fat replacement process where the full replacement of fat with maltodextrin led to obtain the hardest cheese as compared either with other replacement ratios or the control one. This could be ascribed to the strong water holding capacity of maltodextrin which make it acts as a filler and bodying agent. Similar observations were reported by Mounsey and O'Riordan (2001) who demonstrated a positive correlation between the presence of starches and the hardness of cheese. Regarding the $\mathrm{NaCl}$ replacement, the $\mathrm{KCl}$-containing cheeses were softer than the control one. Possibly that is due to the promotion occurred in the proteolysis rate in the presence of potassium versus sodium salt. All cheeses showed significant decrease in their hardness values upon storage. These observations were supported by those of Diefes et al (1993) who reported that, proteolysis by plasmin and residual coagulant causes cheese softening during storage.

Cohesiveness is the strength of internal bonds making up the body of the product as explained by Bourne (2002). It is a parameter for measuring the ability of cheese to adhere with each other. The results reveal that, the control cheese which made without fat replacement possessed the highest cohesiveness of all cheese samples. Possibly due to the increased porosity of the protein matrix of the fat replaced cheeses resulting from the presence of maltodextrin. Similar observations were reported by Bryant et al (1995). The higher fat replacement levels than $50 \%$ had no significant effect on the final cheese cohesiveness. Likewise, the salt replacement led to decrease the cohesiveness of cheese up to the $50 \%$ replacement rate as compared with the control cheese which obtained significant similar cohesiveness to the cheese of $75 \%$ salt replacement rate (Table, 4 ).

Springiness is the rate at which a deformed material returns to its original shape on removal of the deforming force as explained by Bourne (2002). The obtained data indicate that, the fat replacement process had a significant effect on the cheese springiness, where the total fat replacement led to obtain the lowest springy cheese of all samples. That could be due to the dominant role of fat content in raising the springiness of cheese. Similar observations were reported by Bhaskaracharya and Shah (1999) who confirmed that springiness increased with increase in fat content. Moreover, the $\mathrm{NaCl}$ replacement with $\mathrm{KCl}$ at a rate of $50 \%$ led to obtain the highest springy cheese. That could be attributed to the higher protein content of that cheese sample compared either with the control cheese or the other salt replaced ones. That is in agreement with Bhaskaracharya (2004). The springiness values of all cheeses were gradually decreased throughout the cold storage period, possible as a result of proteolysis which increases the fat voids size in the cheese matrix (Table, 4).

Gumminess is the force needed to disintegrate a semisolid food to a state ready for swallowing as explained by Bourne (2002). The results demonstrate that gumminess values of the cast Feta cheese differed significantly by replacing the cheese fat with maltodextrin. The total fat replaced cheese possessed the highest gumminess of all cheeses followed by the cheese of $75 \%$ fat replacement rate, then that of the $50 \%$ fat replacement rate, while the cheese of $25 \%$ fat replacement rate came in the latest order reflecting similar gumminess to the full fat control. Regarding the salt replacement, the results demonstrated that the control cheese which made without $\mathrm{NaCl}$ replacement obtained the lowest gumminess of all cheeses, while the cheese of $75 \%$ salt replacement came in the first order having the highest gumminess of all cheeses. All cheese samples showed a significant decrease in its gumminess by prolonging the cold storage period as a result of the decrease in their hardness (Table, 4).

Chewiness is the work needed to masticate a solid food to a state ready for swallowing as explained by Bourne (2002). It is noteworthy to mention that, regarding the fat replacement, there was strong correlation between the gumminess and chewiness of cheese, where the total fat replacement led to attain the highest significant value of cheese chewiness. However, the lower $\mathrm{NaCl}$ replacement rates had no effect on the cheese chewiness. The chewiness of all cheeses was gradually decreased during storage, possibly due to the decrease in the hardness as well as gumminess (Table, 4). Similar observations were reported by Fayed et al (2013). 


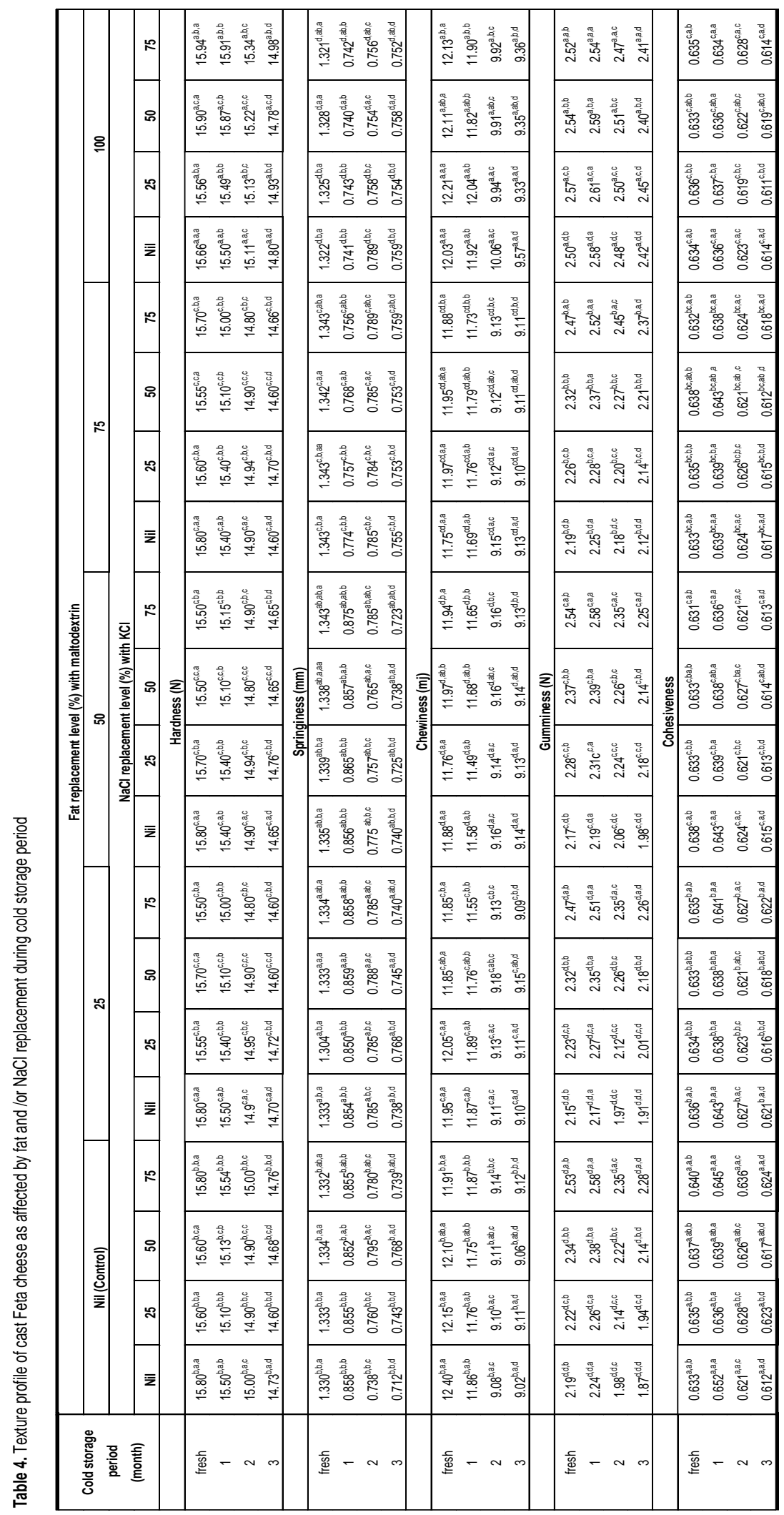




\section{Microbiological situation of cast Feta cheese}

Regarding the total bacterial count (TBC) of cheese, data in Table (5) revealed that, the cheese made with total fat replacement had the highest TBC of all cheeses, while cheeses made with lower fat replacement levels possessed statistical similar TBC to each other as well as to the control cheese. Moreover, replacing the cheese $\mathrm{NaCl}$ with $\mathrm{KCl}$ led to decrease the TBC, and the reduction in TBC increased as the salt replacement level raised. The fresh cheese samples contained the lowest TBC, while the numbers of total bacteria attained its highest values at the end of the first week of storage then slightly declined by prolonging the cold storage period.

Concerning the Yeasts and molds (Y\&M) counts of cheese, the data confirmed that, the fat free cheese gained the lowest Y\&M counts compared either with the full fat cheese or other fat replaced cheese samples (Table, 5). This is Possibly due to that most of milk indigenous yeasts are lipophilic. Replacing the salt with $\mathrm{KCl}$ at a rate of $75 \%$ led to achieve a significant decrease in the counts of $Y \& M$ of cheese. Similar observations were reported by Feng and Zheng (2006), who proved that, the mixing of $\mathrm{KCl}$ with $\mathrm{NaCl}$ led to strength the antifungal capacity of the systems that contains lipids. The counts of Y\&M of all cheese samples were gradually increased by prolonging the cold storage period until the end of experimental period.

\section{Organoleptic quality of cast Feta cheese}

As could be seen in Table (6), all judging scores of cheese sensory attributes were decreased as the fat replacement ratios increased. The main reasons of those reductions were the consistency and rather the flavor scores. Appearance was relatively acceptable in fresh cheese and even maximum fat replacement ratios, while the taste was strongly influenced by the fat replacement ratio. Bullens (1994) and Anonymous (1996) reported that, the relatively low acceptance of reduced-fat cheese has been attributed to poor consumer perception of the products based on taste and texture. Moreover, Hatchwell (1994) confirmed that, off-flavors are not normally perceived in full-fat systems because most are fatsoluble and at or below threshold levels. However, in the absence of fat, the vapor pressure of the aroma chemicals in water is increased resulting in a very intense perception of the chemicals. That means, as the fat provides mouthfeel and richness, it serves also as a reservoir of flavor, whereas, fat interacts with flavor components provided a specific sensory balance.

The substitution of $\mathrm{NaCl}$ with $\mathrm{KCl}$ more than $50 \%$ in cheese salting caused a decline in all scores of cheese sensory properties, especially if fat replacement exceeded 75\%. Demott et al (1984) found that partial $(50 \%)$ substitution of $\mathrm{NaCl}$ with $\mathrm{KCl}$ in Cottage cheese revealed similar acceptability to the full sodium control. Katsiari et al (1997 and 1998) also reported that sodium contents of Feta and Kefalograviera cheeses can be successfully reduced by $50 \%$, when $\mathrm{NaCl}$ is partially replaced with $\mathrm{KCl}$, once gross composition and sensory properties are not affected. This replacement might give the perception of saltiness without undesired flavors. However, the level of substitution of $\mathrm{NaCl}$ by $\mathrm{KCl}$ may be limited by the bitter undesired taste that might be possessed of $\mathrm{KCl}$. While, Breslin and Beauchamp (1997) declared that, in mild flavored cheeses, such as unripened white soft cheeses, at levels of replacements up to $50 \%$, the bitterness would be masked by the remaining $\mathrm{NaCl}$. Whilst, this level of replacement (50\%) might not provide desired characteristic flavors of other types of cheese. However, increasing the substitution of sodium level by more than $50 \%$ results, generally, in a significant decrease in flavor, as it was reported by Demott et al (1984) in Cottage cheese.

During cheese cold storage period all organoleptic attributes scores decreased by prolonging the CSP but still keeping their acceptable panelist quality until the end of experimental period provided that the level of fat replacement does not exceed $75 \%$ and that the level of replacement of sodium chloride does not increase than $50 \%$. 


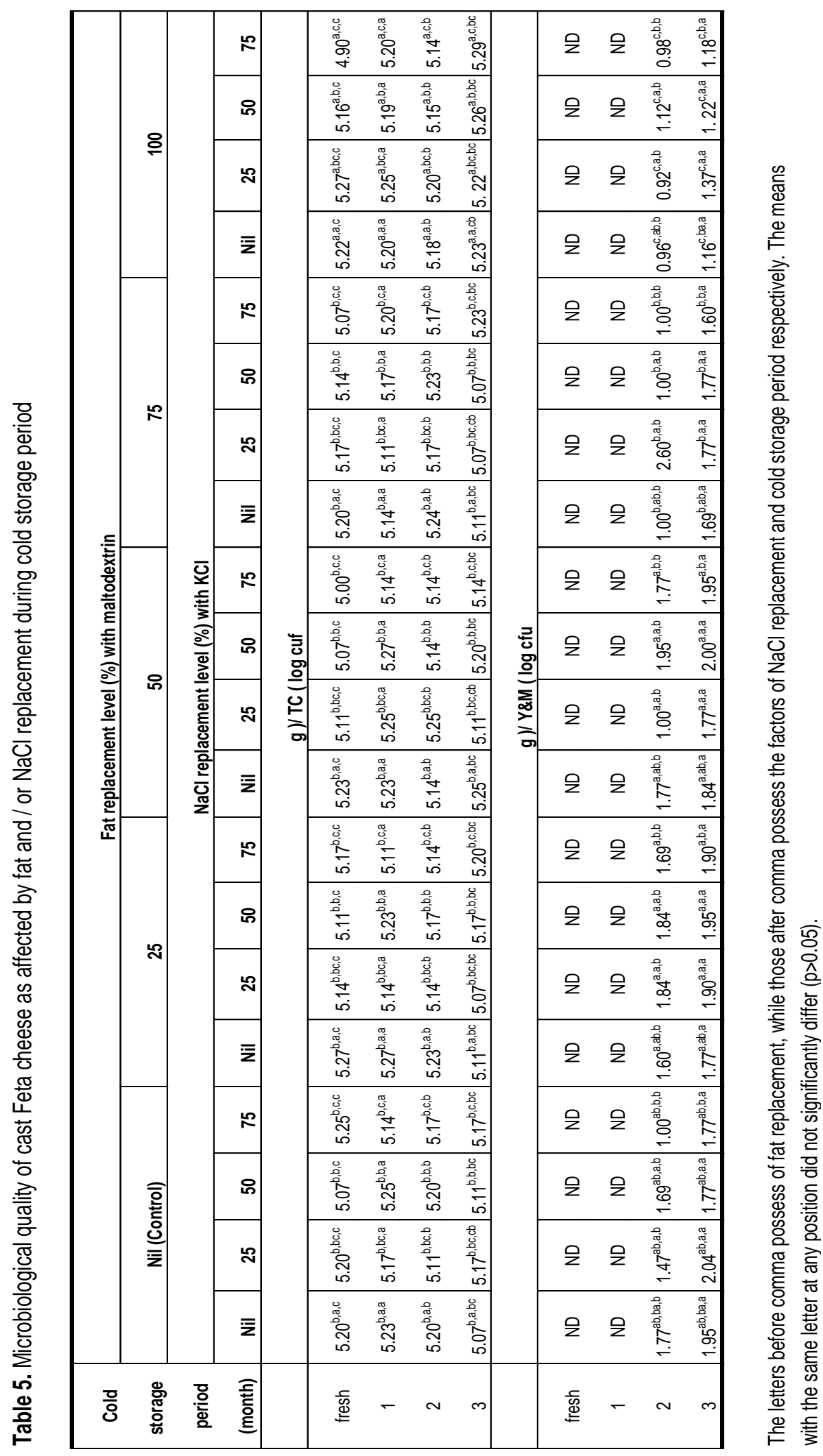




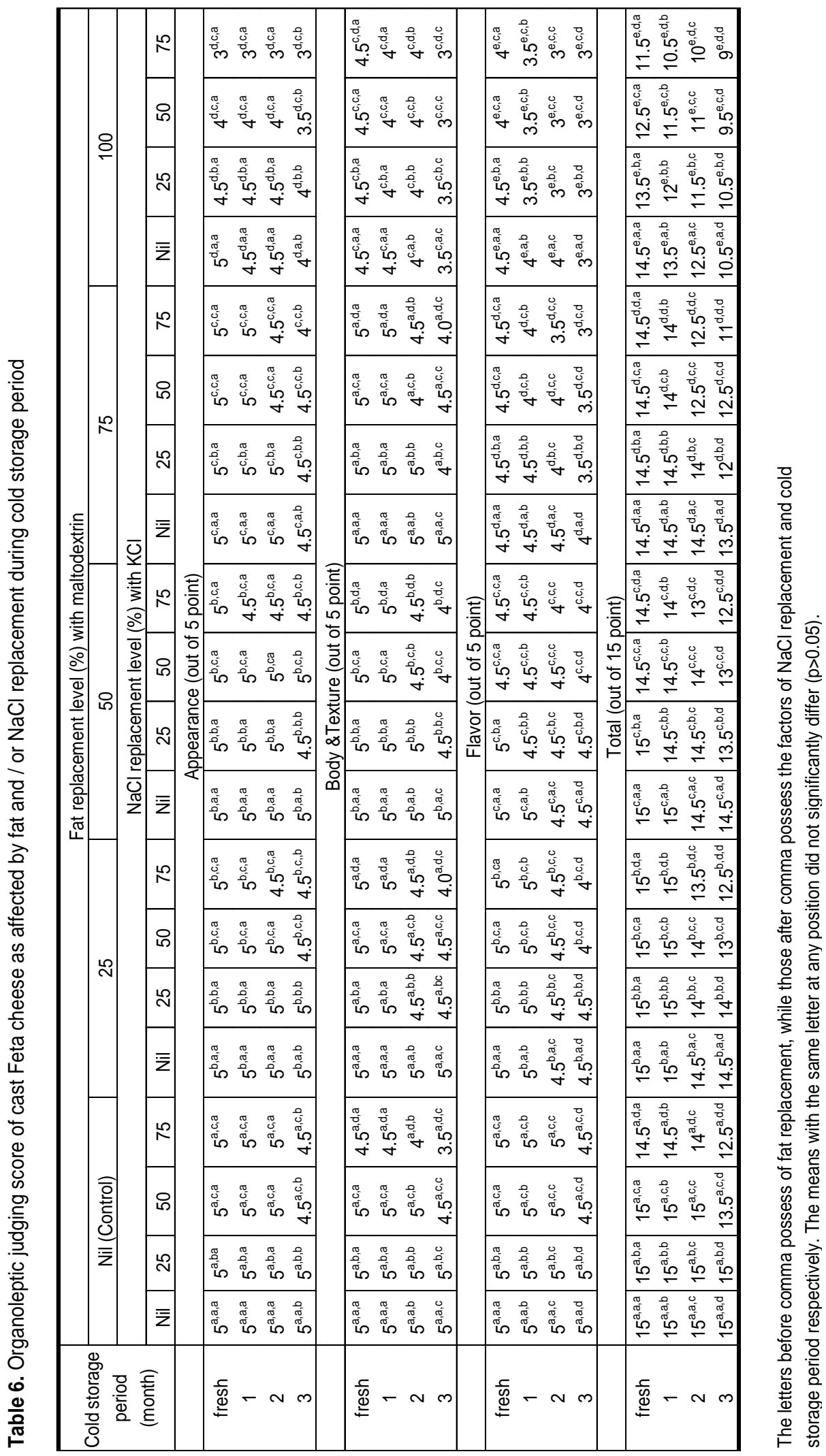




\section{CONCLUSION}

As a conclusion, it could be successfully produce Feta cheese low in energy and sodium with good chemical, rheological and microbiological properties and provided that the fat replacement does not exceed $75 \%$ and the level of sodium chloride substitution does not increase than $50 \%$.

\section{REFERENCES}

Adeniyi O.S. and Fasanmade A.A. 2006. Effect of dietary zinc sulphate supplementation on salt induced hypertension in rats. Int. J. Pharmacol., 2, 485-491.

Anonymous 1996. UK lite hard cheese market. Low and Lite Digest., 1(7), 8-11.

AOAC 2012. Association Official Methods of Analysis, $18^{\text {th }}$ Edition AOAC International Gaithersburg, MD. No. (9685.080), and CH.4, p. 56-57 and No.(985.01), ch.3, p.6.

APHA 1992. American Public Health Association. Standard Methods for the Examination of water and Wastewater. 18 ${ }^{\text {th }}$ Ed., Washington, D.C., USA.

Bhaskaracharya R.K. 2004. Development of Low Fat and Reduced Fat Mozzarella Cheese. Ph.D. Thesis, School of Molecular Sci., Victoria Univ., Victoria, Austrailia, pp. 260-267.

Bhaskaracharya R.K. and Shah N.P. 1999. Texture evaluation of commercial Mozzarella cheeses. Aust. J. Dairy Technol., 54, 36-40.

Bourne M.C. 2002. Food Texture and Viscosity: Concept and Measurement. $2^{\text {nd }}$ Ed., Elsevier Sci. Technol. Books, UK., pp. 189-233.

Breslin P.A. and Beauchamp G.K. 1997. Salt enhances flavour by suppressing bitterness. Nature, 387, 563.

Bryant A., Ustunol Z. and Steffe J. 1995. Texture of Cheddar cheese as influenced by fat reduction. J. Food Sci., 60, 1216-1219.

BSI 1990. British Standards Institution. Testing aggregates. General requirements for apparatus and calibration. BS 812: Part 100, BSI, London, UK.

Bullens C. 1994. Reduced-fat Cheddar. Aspects of process and ingredient effect. World of Ingredients (Oct.-Nov.), 28-31.

Cruz G.J.,. Faria A.F., Pollonio M.A.R., Bolini H.M.A., Celeghini R.M.S., Granato D. and Shah N.P. 2011. Cheeses with reduced sodium content: Effects on functionality, public health benefits and sensory properties. Trends in Food Sci. \& Technol., 22, 276-291.
Demott B.J., Hitchcock J.J. and Sanders O.G. 1984. Sodium concentration of selected dairy products and acceptability of a sodium substitute in Cottage cheese. J. Dairy Sci., 67, 15391543.

Dexheimer E. 1992. On the fat track. Dairy Foods. 93, 38-50.

Diefes H.A., Rizvi S.S.H. and Bartsch J.A. 1993. Rheological behaviour of frozen and thawed low moisture, part skim Mozzarella cheese. J. Food Sci., 58, 764-769.

Doyle M.E. and Pariza M.W. 2002. Antioxidant nutrients and protection from free radicals. In: Nutritional Toxicology. (F.N. Kotsonis, M. Mackey and J. Hjelle, Eds.), Raven Press Ltd., New York, USA, pp. 1-30.

Drake S.L., Lopetcharat K. and Drake M.A. 2011. Salty taste in dairy foods: can we reduce the salt? J. Dairy Sci. 94, 636-645.

El-batawy M.A., Galal E.A., Morsy M.A. and Abbas A.A. 2004. Utilization of ultrafiltration technique in making Mozzarella cheese from different kinds of milk. Egypt. J. Dairy Sci., 32, 303-314.

El-Sayed R.M., Awad R.A., Fayed A.E. and Khalafalla S.M. 2003. Production of low calorie ice cream. Res. Bult., Ain Shams Univ., Cairo, Egypt. pp. 1- 13.

EOSQ 2005. Egyptian Organization for Standardization and Quality. Egyptian Standards. D1 Food/2005. Guide Lines for Quality Criteria for Milk and Milk Products.

Fayed A.E., Farahat A.M., Metwally A.E., Massoud M.S. and Emam A.O. 2013. Rheological, microstructural and biological characteristics of probiotic ultrafiltrated skimmed milk cheese in comparison with the conventional Kariesh cheese. Proc. 6 ${ }^{\text {th }}$ Ann. Appl. Res. Environ. Prot. and Agric. Dev., Feb. 27-28. and J. Biol. Chem. Environ. Sci., 8, 163-198.

Fenelon M.A., O'Connor P. and Guinee T.P. 2000. The effect of fat content on the microbiology and proteolysis in Cheddar cheese during ripening. J. Dairy Sci. 83, 2173-2183.

Feng W. and Zheng X. 2006. Control of alternaria alternata by cassia oil in combination with potassium chloride or sodium chloride. J. Appl. Microbiol. 101, 1317-1322.

Guinee T.P. and McSweeney P.L.H. 2006. Significance of milk fat in cheese. In: Advanced Dairy Chemistry-2. Lipids, $3^{\text {rd }}$ Ed., (P.F. Fox and P.L.H. McSweeney, Eds.), Springer Publishers, New York, USA, pp. 377-440. 
Hatchwell L.C. 1994. Overcoming flavor challenges in low-fat frozen desserts. Food Technol., 48, 98-102.

Kaplan N.M. 2000. The dietary guideline for sodium: should we shake it up? Amer. J. Clin. Nutr., 71, 1020-1026.

Katsiari M.C., Voutsinas L.P., Alichanidis E. and Roussis I.G. 1998. Manufacture of Kefalograviera cheese with less sodium by partial replacement of $\mathrm{NaCl}$ with $\mathrm{KCl}$. Food Chem., 61, 63-70.

Katsiari M.C., Voutsinas L.P., Alichanidis E. and Roussis I.G. 1997. Reduction of sodium content in Feta cheese by partial substitution of $\mathrm{NaCl}$ by KCl. Int. Dairy J., 7, 465-472.

Ling E.R. 1963. A text book of dairy chemistry. Vol. 2. $3^{\text {rd }}$ ed., Champon and Hall, London, UK.

Mounsey J.S. and O'Riordan E.D. 2001. Characteristics of imitation cheese containing native starches. J. Food Sci., 66, 586-591.
O'Brien N.M. and O'Connor T.P. 2004. Nutritional aspects of cheese. In: Cheese Chemistry, Physics and Microbiology. Vol. 1, General Aspects, $3^{\text {rd }}$ Ed. (P.F. Fox, P.LH. McSweeney,T.M. Cogan, T.P. Guinee, Eds.), pp. 573-581.

Pearce L.E. and Heap H.A. 1974. Town milk. J. New Zealand Milk Board, 22, 18-22.

Salahdeen H.M. and Alada A.R.A. 2007. Cardiovascular response to angiotensin II and captopril in normal and diabetic rats loaded with salt. J. Med. Sci., 7, 187-194.

SAS 1996. Statistical Analysis System. SAS user's guide. Statistics. SAS Inst. Inc. Ed., Cary, NC, U.S.A.

Tamime A.Y. 2006. Brined Cheeses. Blackwell Publishing, Oxford, UK.

Tunick M.H., Holsinger V.H., Mackey K.L. and Smith P.W. 1991. Effects of composition and storage on the texture of Mozzarella cheese. Neth. Milk Dairy J., 45, 117-125. 


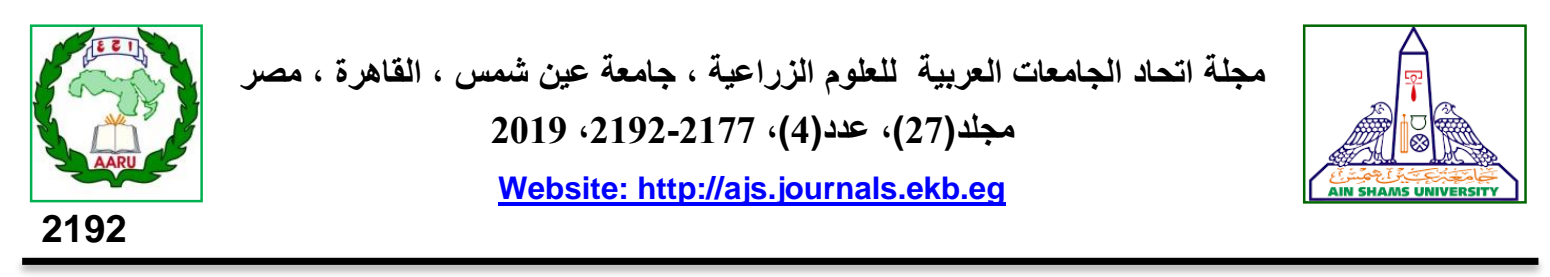

إنتاج جبن فيتا مصبوب منخفض السعرات الحرارية والصوديوم

$[173]$

أحمد محمد الأزهري1" - ميراندا عبد المجلى توفيق1 - أحمد أسامة إمام2 - عاطف السيد فايد2

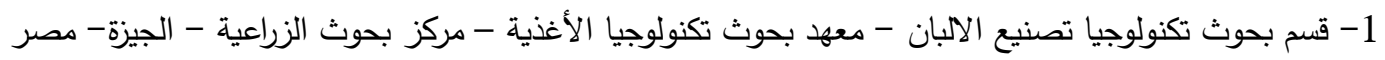

2- قسم علوم الأغذية - كلية الزراعة - جامعة عين شمس - ص.ب. 68 - حدائق شبرا 11241 - القاهرة -

*Corresponding author: ahmedmohe530@gmail.com

Received 18 September, 2019

Accepted 4 November, 2019

بزيادة نسبة استبدال الدهن. كماز زادت كلا من الصلابة،

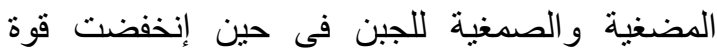
التماسك باستبدال الدهن. زاد العدد الكلى البكتيريا، بينما

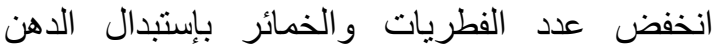
بالمالتوديكسترين. ولقد انخفضت جميع درجات التفئر التحكيم

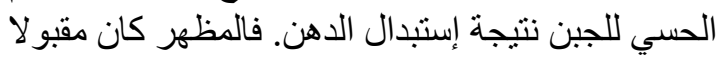

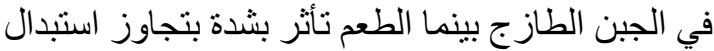

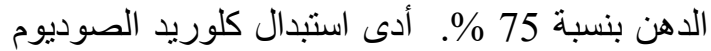

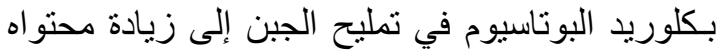

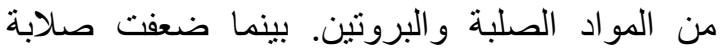
الجبن في حين تحسنت الصمغية والذى الدئ أدى إلى الى

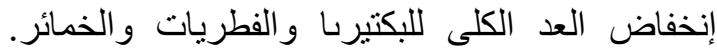

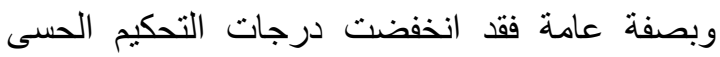

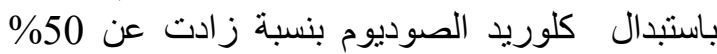

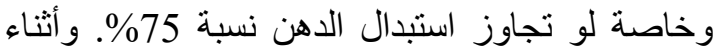

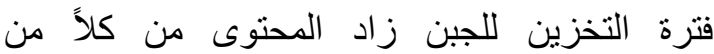

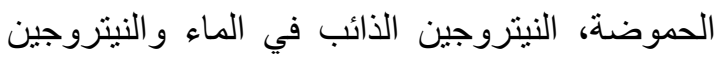
غير البروتيني منسوبين للنيتروجين الكلى وكنللك عدد اللئ

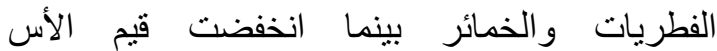

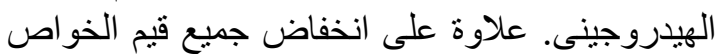
الريولوجية والحسية للجبن أثناء التخزين ولكنها ظلتي فئل محتفظة بدرجة القبول لاى المحكمين حتى نهاية فترة

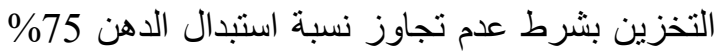

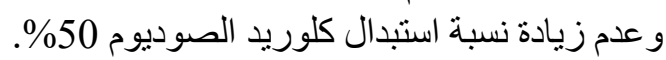
الكلمات الدالة: التركيب الكيميائى، دلالات التسوية،

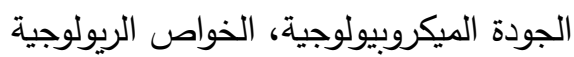

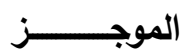

تم دراسة انتاج جبن فيتا مصبوب منخفض الطاقة وذللك بالاستبدال الجزئى أو الكلى لدهن اللبن ودئ وكلوريد

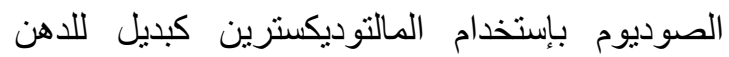
وكلوريد البوتاسيوم كبديل في التمليح. تم حسابيا خلط لإني

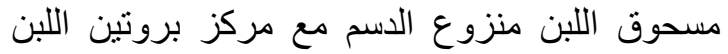

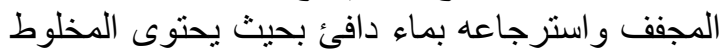

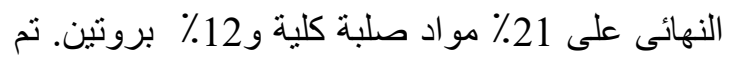

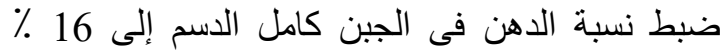

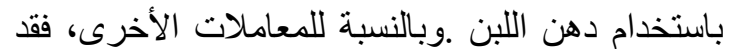

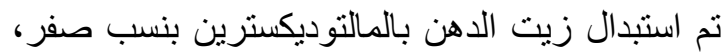

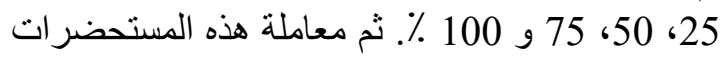

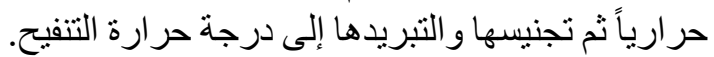
تم إضافة سوربات البوتاسيوم بنسبة 0.015 ٪ و التمليح

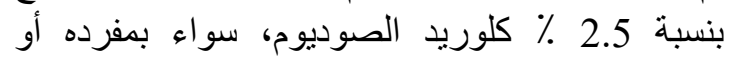

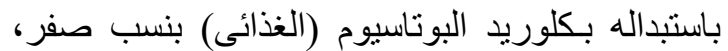
25 ، 50 و 75 \%. كما أضيف الجلوكونو دلتا لاكتون الغناني

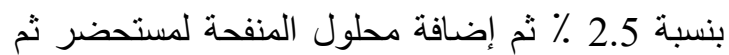
التعبئة في عبوات بلاستيكية وتحضينها حتى تمام التجبن. ثم تخزين بالثلاجة لمدة 3 أنشهر. أثنارت النتائج

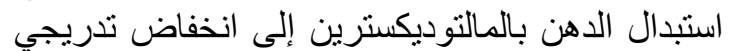

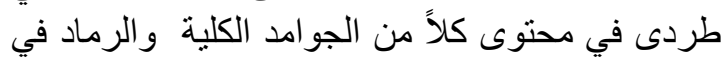

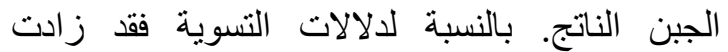
الحموضة ومحتوى النيتروجين الذائب في المين النياء والنيتروجين غير البروتيني منسوبين للنيتروجين الكلى 
